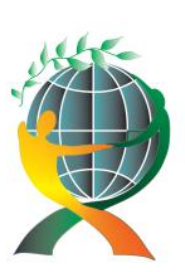

\author{
(online) $=$ ISSN $2285-3642$ \\ ISSN-L = 2285 - 3642 \\ Journal of Economic Development, Environment and People \\ Volume 3, Issue 2, 2014 \\ URL: http://jedep.spiruharet.ro \\ e-mail: office jedep@spiruharet.ro
}

\title{
Consumer attitude and behavior towards Bio-products in Slovak Republic
}

\author{
Ing. Jana Chovancová $\mathrm{PhD}^{1}$, Ing. Emília Huttmanová PhD² \\ ${ }^{1}$ University of Prešov in Prešov, Faculty of Management, Department of environmental management, \\ 17. novembra 1, 08001 Prešov \\ jana.chovancova@unipo.sk \\ ${ }^{2}$ University of Prešov in Prešov, Faculty of Management, Department of environmental management, \\ 17. novembra 1, 08001 Prešov \\ emila.huttmanova@unipo.sk
}

\begin{abstract}
Bio-product market is very challenging and developing rapidly. Consumers have raised great interest in healthy and tasty diet with high nutritional compounds, confidence in food safety, environmental and animal welfare concern and also sustainability. The aim of this paper is to analyze consumer attitude and behavior as well as the factors influencing purchasing behavior when deciding to buy bio-products or their substitutes. The essential part of the article presents the partial results of the research, which was directed to consumers buying bio-products in Slovakia.
\end{abstract}

Keywords: consumer attitude, purchasing behaviour, bio products, sustainability.

JEL Codes: Q01, Q57

\section{Introduction}

In recent years we have witnessed a variety of adverse changes to the environment by increasing production in the agricultural sector using excessive amounts of fertilizers and chemicals. Environmental problems and related health issues leaded in the $80 \mathrm{~s}$ of last century to preference of alternative/ environmental management systems, through which the negative impacts on the environment was minimized, but they also served as a basis for creating integrated, humane and both economically and environmentally sustainable agricultural production system.

Health concerns and many scandals accompanied food production and products in the last few years trigged the attention of consumers towards bio-products. In the society is now formed an increasing consumer group for which quality is more than just a low price. Also the area of land farmed organically in Slovakia as well as other European countries increased significantly. In this way consumers have great 


\author{
(online) $=$ ISSN $2285-3642$ \\ ISSN-L = $2285-3642$ \\ Journal of Economic Development, Environment and People \\ Volume 3, Issue 2, 2014 \\ URL: $\underline{\text { http://jedep.spiruharet.ro }}$ \\ e-mail: office jedep@spiruharet.ro
}

opportunity to chance current trends in development of agriculture and food industry via their interest, preference and demand of bio-products.

Despite increasing awareness and growing demand for bio-products, Slovak market is taking off rather slowly. Presented paper is focused on assessment of consumers' awareness of bio-products as well as on factors influencing their behavior when purchasing bio-products. Based on information gathered through a questionnaire the measures that would increase awareness and consequently the interest of Slovak consumers of these products were outlined.

\title{
2. Ecological farming in Slovakia
}

Halberg (2006) defines ecological or organic agriculture as management system which promotes and enhances agro-ecosystem hygiene, including biodiversity, biological cycles and soil biological activity. Emphasizes the use of economic practices favouring corporate inputs, uses environmentally friendly methods of agronomy, biological and mechanical methods, as opposed to synthetic substances; in livestock farming, emphasis on animal welfare, care to the overall harmony of agro-ecosystem and its biodiversity and favours renewable resources and recycling materials. Organic farming is consistent with the principle of sustainable development of agriculture, and performs not only the production function, but especially nonproductive environmental protection and sustainability of country.

Development of agricultural land in Slovakia shows increased interest in organic agriculture. In 2012, the number of hectares farmed organically almost tripled in comparison with 2000 and reached the level of 168 thousand hectares, representing 8.75\% of the whole agricultural land in Slovakia. In 2013 there were 448 registered operators in the system of organic farming. (Central Controlling and Testing Institute in Agriculture, 2013).

\section{Consumer attitude and behaviour}

Consumer behaviour reflects the variety of consumer decisions regarding the needs, activities, people's experiences, opinions and ideas, and ultimately the properties of products through personal choice (Hoyer and Macinnis 2010).

Kretter (2005) states that "the need of a product is the decisive factor in the purchase of the product and the need reflects the motives which stimulate the buyer". This can be applied to bio-products, too.

The same author defines the predominant motive for their purchase:

- protection of the environnent,

- health reasons,

- healthy life style,

- trying new trend in the diet, 


\author{
(online) $=$ ISSN $2285-3642$ \\ ISSN-L = 2285 - 3642 \\ Journal of Economic Development, Environment and People \\ Volume 3, Issue 2, 2014 \\ URL: $\underline{\text { http://jedep.spiruharet.ro }}$ \\ e-mail: office jedep@spiruharet.ro
}

- promotion of organique farming,

- less or no chemical substances used in manufacturing,

- better taste and quality.

According to Blair (2012) a key motive for buying organic products is their health safety. Author includes other factors such as the perception of food quality, taste, consistence, as well as nutritional value. Finally, the author adds the factors of humane treatment of animals and environmental sustainability of production processes.

Lieskovská (2012), on the other hand, identifies barriers, which also influence the behaviour of consumers of organic food and considers them as a problem when purchasing bio-products. These barriers are:

- qualitative barrier - some bio-products are characterized by unusual taste, odor or appearance,

- price barrier - is among the most important factors; high price discourages consumers,

- situational barrier - usually some bio-products are not available in all places,

- habit barrier - consumers are accustomed to buying everything under one roof, they do not like searching for other stores where they can buy bio-products,

- motivational barrier - a real lack of interest in bio-products and the environment,

- Information barriers - arise if the consumer has little knowledge about the benefits of bio-products,

- Barrier of trust - deficit of information or negative previous experience of bio-products causes mistrust of consumers.

\title{
4. Research
}

The goal of the research was to analyse tendencies in attitude and buying behaviour of customers as well as factors influencing their behaviour when buying bio products.

\subsection{The research methodology and research sample}

To achieve the main objective the following research methods were used:

- Analysis of secondary sources, such as a scientific literature and research articles and surveys published in domestic and foreign journals and proceedings relating to issues of bio-products. In addition to these sources of information the relevant websites and legislative documents were examined.

- Performing a questionnaire survey.

- Using the method of comparison, induction and deduction in information processing. 


\author{
(online) $=$ ISSN $2285-3642$ \\ ISSN-L = $2285-3642$ \\ Journal of Economic Development, Environment and People \\ Volume 3, Issue 2, 2014 \\ URL: $\underline{\text { http://jedep.spiruharet.ro }}$ \\ e-mail: office jedep@spiruharet.ro
}

The questionnaire survey was performed on a sample of 312 respondents. We contacted various categories of people, whether in terms of age, gender and economic issues such as monthly income. Respondents were anonymous and they responded questionnaire via electronic form, as well as a printed form. The survey was conducted in February and March 2014 and the results of this survey were processed in April 2014.

\title{
4.2. Results and interpretation of data
}

The questionnaire begins with some demographic questions (age, gender, number of people in the household, education level, occupation status and income questions) for statistical analysis. The next part of questionnaire is focused on consumers' awareness of bio-products. Survey has showed that 281 (90\%) respondents are aware of bio-products and only 31 (10\%) does not know what bio-products are. Respondents mostly consider as bio- products "products of organic farming, which do not contain chemical compounds" or "are not produced with the help of synthetic fertilizers."

From the group of respondents which reported that they are informed about bio-products, only 82 (29 $\%)$ answered that they buy this products. 129 respondents (46\%) stated that they purchase bio-products occasionally and 70 respondents stated that they never buy bio-products, which represents $25 \%$.

This indicates quite big difference between awareness of bio-products and their real buying. Pickett Baker, Ozaki (2008) refer to it as Ethical Purchasing Gap. It confirms a presumption that despite of general awareness of health or environmental issues it does not significantly shift the buying behaviour of consumers.

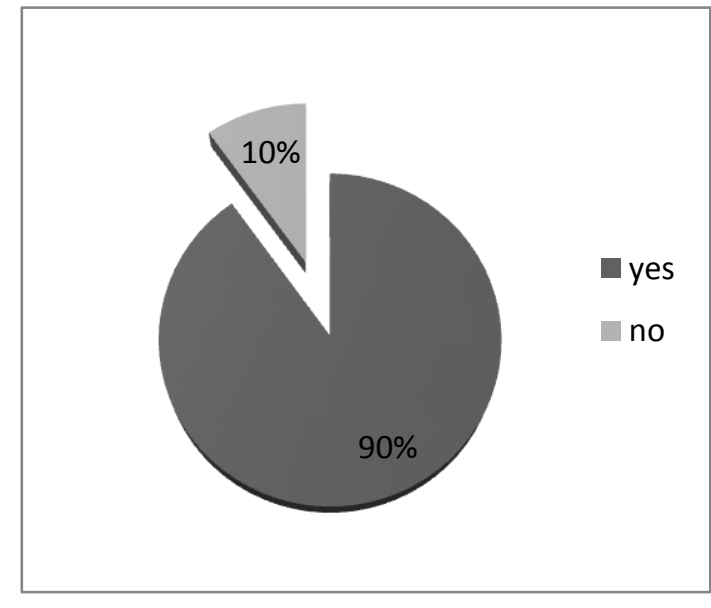

Fig. 1: Awareness of bio-products

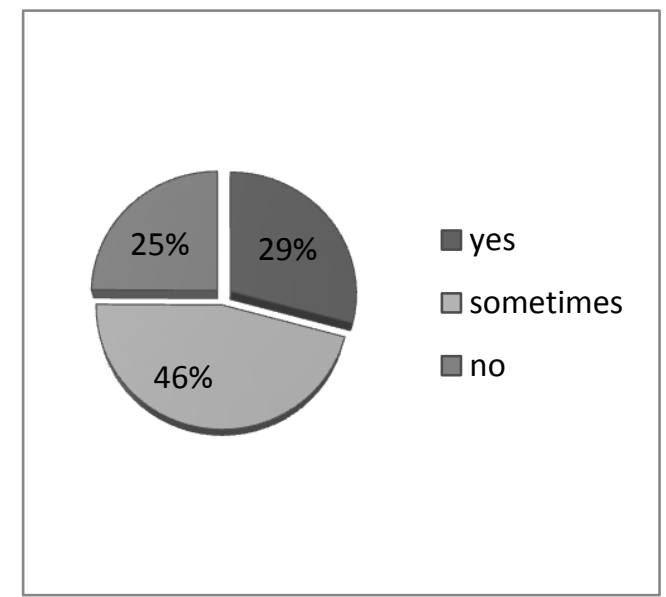

Fig. 2: Buyng bio-products

Consumers of bio-products can be influenced by many factors. The attitude measurement question was directed to respondents using 5 point Likert scale from "not important at all" to "strongly important" focused to measure, which factor influence attitude towards buying bio-products. Results can be seen on figure 3 . 


\author{
(online) = ISSN $2285-3642$ \\ ISSN-L = 2285 - 3642 \\ Journal of Economic Development, Environment and People \\ Volume 3, Issue 2, 2014 \\ URL: $\underline{\text { http://jedep.spiruharet.ro }}$ \\ e-mail: office jedep@spiruharet.ro
}

Taste and appearance - eating tasty food is a general motive for everybody to satisfy our needs. Most bio-product consumers think that these products taste more natural, intense and rich in flavour. Slovak bioproduct consumers are mostly affected by the taste of the organic products, as it is shown in the graph. Also western European studies showed that taste is one of the main motives for buying bio-products. (Hofmann, 2006)

Price - bio-product price differences are ranging from 40 to $450 \%$ when compared to conventional products and usually price remain the major factor influencing the people choice. Especially in developing markets in Eastern Europe, bio-product prices can be really high that only high income class can be able to purchase them. Results on our survey showed that for Slovak consumers the price is in the second place as a factor influencing bio-product purchasing.

Availability - for most consumers to go shopping nearby the house become a routine work and a way of time and money saving. Even if they want to buy bio-products, they cannot reach the products in daily life. As is evident from the graph, under the criteria of availability of organic products on the market, most respondents did not have a strong opinion and availability as a criterion is not considered as the most important in purchasing decisions on buying bio-products.

Environmental protection - rising concerns about environment and resources are motives for majority of bio-products consumers but not the main or strong reason. In our survey this factor reached the fourth place.

Promotion - the least important factor influencing consumers when buying bio-products is promotion. We should state that bio-products are not promoted very often in Slovakia. Slovak consumers also have a problem with eco-labels recognition.

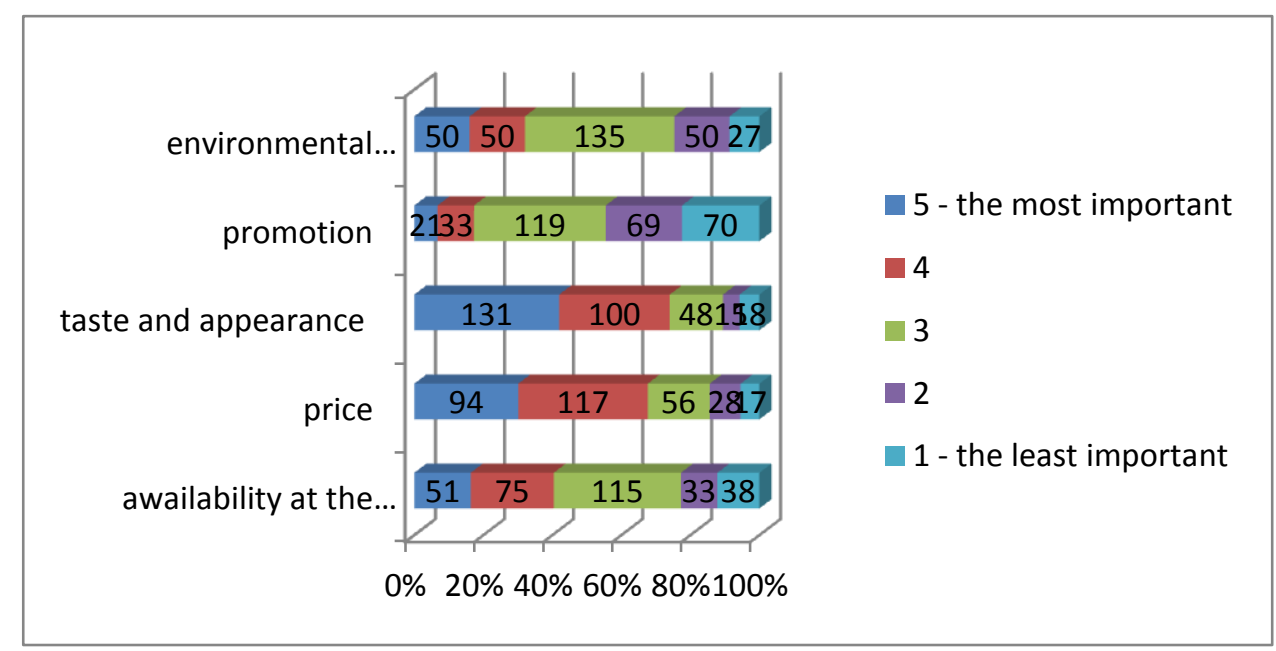

Fig. 3: Factors influencing consumers when buying bio-products 


\author{
(online) $=$ ISSN $2285-3642$ \\ ISSN-L = 2285 - 3642 \\ Journal of Economic Development, Environment and People \\ Volume 3, Issue 2, 2014 \\ URL: $\underline{\text { http://jedep.spiruharet.ro }}$ \\ e-mail: office jedep@spiruharet.ro
}

The last question on our survey monitored the opinions of consumers how could be marketability of bio-products improved. Respondents could choose more answers. The most of them suggested decreasing the prices of bio-products. Other options according to respondents would be better availability, more rational life style of Slovaks and increased consumer awareness. In the last place consumers would appreciate wider range of goods.

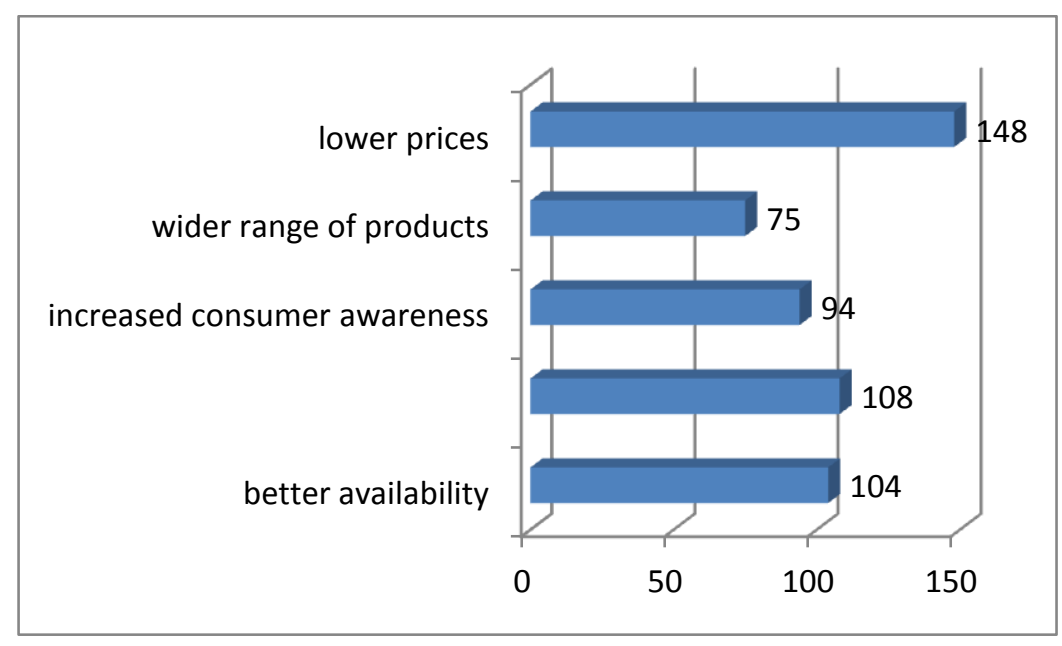

Fig. 4: Improving the marketability of bio-products - opinion of respondents

We can conclude that Slovak bio-product market is very challenging. In the discussion we offer some suggestions how this challenge can be dealt with.

\title{
5. Discussion
}

With an increasing awareness of bio-products consumers in Slovakia, producers and retailers need to understand and meet the needs of this growing group of customers. Our research revealed that customers are aware of bio-products, though they have problems with eco-label or bio-product labels recognition. The most important factor influencing their purchasing behavior is taste and appearance of bio-products, on the second place respondents stated price. In respondents' opinion lower prices would enhance Slovak customers to buy bio-products. Based on results of survey we can suggest some measures to improve bioproduct market position:

Promotion - promotion of bio-products in comparison with promotion of conventional products is considerably minor. Bio-product promotion is most often in magazines, or web pages devoted to bio or healthy life-style. In the media like television and radio is a substantial lack of the bio-product advertising. Producers and retailers should use this tool to increase interest of consumers in bio-products. Though the most effective and cheapest is the word-of-mouth advertising made by satisfied customer. Important role 


\author{
(online) = ISSN $2285-3642$ \\ ISSN-L = 2285 - 3642 \\ Journal of Economic Development, Environment and People \\ Volume 3, Issue 2, 2014 \\ URL: $\underline{\text { http://jedep.spiruharet.ro }}$ \\ e-mail: office jedep@spiruharet.ro
}

in bio-products advertising plays logo of bio-products. Also government should advertise bio-label better in Slovakia.

Price of bio-products - survey showed that respondents perceive the price of bio-products as relatively high. (This factor is in strong correlation with income of household). Higher price of bio-products is usually caused by higher cost of production processes, which are usually based on natural principles and they are also more demanding of human labor. Prices of bio-products can be slightly reduced via EU's generous subsidy policy for bio-producers, small and family farms. It can enhance also organic agriculture in Slovakia.

\title{
6. Conclusion
}

In this paper the consumer attitude and behaviour towards bio-products was examined. Survey confirmed that many people are already aware of bio-products and through their buying preferences also present certain lifestyle, part of which becomes even more intense in consumption of organic or bioproducts. The task of this time is to find a way how to connect the nature with available technological capabilities and scientific knowledge so that we can move towards sustainable development of the whole society.

In conclusion, further research with an expanded survey and increased number of respondents can report better results. Apparently, Slovakia should make more consumer studies and carefully examine the market barriers as well as chose effective tools of promotion of bio-products and increase consumers' awareness.

\section{Acknowledgements}

The study was supported by KEGA 032PU-4/2014.

\section{References}

[1] Adamišin, P. 2008. Metodologické prístupy hodnotenia environmentálnych investícií z ekonomického hladiska. In: Zborník vedeckých prác Katedry ekonómie a ekonomiky ANNO 2008. Prešov : PU, 2008, s. 8 -14, ISBN 978-809068-798-4.

[2] Blair, Robert, 2012. Organic Production and Food Quality: A Down to Earth Analysis. 1. ed. Oxford: WileyBlackwell. ISBN 978-0-8138-1217-5

[3] Central controlling and testing institute in agriculture: Annual report 2013. On line 12.6.2014 http://www.uksup.sk/spravy/vyrocna sprava UKSUP 2013.pdf

[4] Chovancová, J. 2011. Systémy environmentálneho manažérstva. Prešovská univerzita v Prešove, 2011, ISBN 97880-555-0485-8

[5] Duguleana, Liliana and Simona Popovici, 2011. The factors which influence the consumption of bio products. In: Bulletin of the Transilvania University of Braşov, Vol. 4 No. 2 [online]. Brasov: Transilvania University of BrasovSeries p. 33-40[cit. 2013-03-24]. ISSN 2065-2194 


\author{
(online) = ISSN $2285-3642$ \\ ISSN-L = $2285-3642$ \\ Journal of Economic Development, Environment and People \\ Volume 3, Issue 2, 2014 \\ URL: $\underline{\text { http://jedep.spiruharet.ro }}$ \\ e-mail: office jedep@spiruharet.ro
}

[6] Givens, lan and col., 2008. Health benefits of organic food: Effects of the environment. 1. ed. Wallingford: CABI Publishing. ISBN 978-1-84593-459-0

[7] Halberg, N. and col., 2006. Global development of organic agriculture: Challenges and prospects. 1. ed. Oxford: CABI Publishing. ISBN 978-18-4593-078-3

[8] Hofmann, S. 2006. The market for organic food from the perspective of consumers and market actors - Analysis of supply chain and demand. Landwirtschaftlich. University of Berlin

[9] Hoyer, Wayne and Deborah MACINNIS, 2010. Consumer behavior. 5. ed. South Western College: Nelson Education. ISBN 978-03-2483-427-7

[10] Huttmanová, E. - Synčáková, L. (2009). Dimensions for evaluation of sustainable development and human development. In Hradecké ekonomické dny 2009: ekonomický rozvoj a management regionů; Hradec Králové: Gaudeamus, 2009. ISBN 978-80-7041-455-2, p. 204-211

[11] Kretter, Anton, 2005. Marketing ekologického pol'nohospodárstva a ekoproduktov. 1. vyd. Nitra: Slovenská pol'nohospodárska univerzita. ISBN 80-8069-620-9

[12] Lieskovská, V. a kol.,2012. Retail manažment bioproduktov. 1. vyd. Bratislava: EKONÓM. ISBN 978-80-225-3387-4

[13] Ministry of agriculture SR. 2006. Action plan for development of organic farming in the Slovak Republic to the year 2010, accepted in 17. March, 2005.

[14] Pickett - Baker, J. - Ozaki, R. 2008. Pro-environmental products: marketing influence on consumer purchase decision. In: Journal of consumer Marketing, vol. 25, p. 281-293, ISSN 0736-3761

[15] Tej, J. (2008). Regionálny manažment - strategická forma partnerstva pri dosahovaní vy̌̌šej regionálnej konkurencieschopnosti. In Konkurencieschopnost' a regionálny rozvoj. Košice : Technická univerzita v Košiciach, Ekonomická fakulta. ISBN 978-80-553-0111-2. p. 49-171 